\title{
Anna Ruzik-Sierdzińska
}

\section{Krótkookresowe skutki programu Rodzina 500+}

\section{Streszczenie}

Głównym celem artykułu jest omówienie dotychczasowego wpływu programu Rodzina 500+ na trzy obszary: liczbę urodzeń, ubóstwo w rodzinach $z$ dziećmi i aktywność zawodową rodziców (zwłaszcza matek) małych dzieci. Wykorzystano dostępne dane statystyczne oraz wyniki kilku badań na ten temat.

Wyniki analiz pokazały, że nowe świadczenie obniżyło poziom ubóstwa wśród rodzin z dziećmi, zwiększyło liczbę urodzen - choć może to być efekt przejściowy i związany także z innych zmianami wprowadzanymi w latach 2013-2016 - a także zmniejszyło aktywność zawodową, głównie kobiet.

Słowa kluczowe: Rodzina 500+, ubóstwo, rynek pracy, dzietność

\section{“Family 500+” Programme: Short-Term Effects}

\begin{abstract}
The main aim of this paper was the analysis of the impact of the "Family 500+" social programme in three areas: fertility, poverty in families with children, and the labour market participation of parents (mainly mothers) with young children. Statistical data available to date has been used by the author.

The results show that the new benefit decreased the risk of poverty in families with children, had an impact on the higher number of births - which could be a temporary effect or a result of other family policy reforms implemented in 2013-2016 - and it decreased female labour market activity.
\end{abstract}

Keywords: "Family 500+", poverty, labour market, fertility 
Systemy świadczeń dla rodzin z dziećmi różnią się w poszczególnych państwach rozwiązaniami szczegółowymi. Wiąże się to $\mathrm{z}$ różnymi celami polityki rodzinnej, przyjętymi jako priorytetowe. Można spotkać systemy finansowane z wpływów podatkowych, ze składek na ubezpieczenia społeczne albo mieszane. Wysokość świadczeń może być stała lub zależeć od liczby dzieci, ich wieku czy niepełnosprawności, wreszcie mogą to być świadczenia uniwersalne lub przyznawane z uwzględnieniem kryterium dochodowego.

Różnorodność rozwiązań skutkuje odmiennymi poziomami wydatków na ten rodzaj polityki, w zależności od przyjętego modelu i struktury demograficznej kraju. Dane Eurostatu zbierane na podstawie jednolitej klasyfikacji wydatków publicznych COFOG (1999) pokazują, że Polska w 2016 r. wydała na politykę społeczną w sumie 16,9 proc. $\mathrm{PKB}$, a na politykę rodzinną 2,5 proc. $\mathrm{PKB}$. Był to wzrost w porównaniu do 2015 r. o 0,9 proc. PKB w wypadku polityki społecznej i aż o 1,1 proc. PKB dla polityki rodzinnej (rysunek 1). Relatywnie duże wydatki na ten obszar polityki publicznej są skutkiem m.in. wprowadzenia w 2016 r. programu Rodzina 500+, który spowodował, że Polska przesunęła się z grupy krajów Unii Europejskiej mniej hojnych do grupy państw szczególnie szczodrych dla rodzin $\mathrm{z}$ dziećmi ${ }^{1}$.

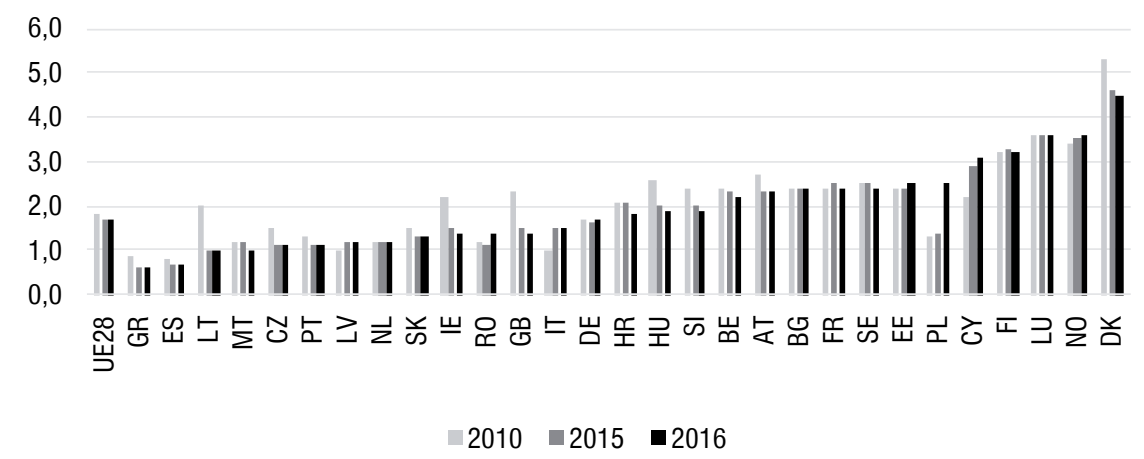

Rysunek 1. Wydatki na politykę rodzinną w krajach Unii Europejskiej w latach 2010, 2015 i 2016 jako proc. PKB kraju

Źródło: opracowanie własne na podstawie danych Eurostat (COFOG, 1999).

Zgodnie z przepisami, świadczenie w wysokości 500 PLN miesięcznie przyznawane jest rodzinom z dziećmi do 18. roku życia. Świadczenie na pierwsze dziecko przysługuje tylko gospodarstwom domowym z miesięcznym dochodem netto

1 Program Rodzina 500+ funkcjonuje od kwietnia 2016 r., a zatem można oczekiwać, że w 2017 r., w którym świadczenie było wypłacane przez całe 12 miesięcy, w jeszcze większym stopniu wpłynął na podniesienie wydatków na politykę rodzinną. 
na osobę nieprzekraczającym 800 PLN (1200 PLN, gdy w rodzinie jest dziecko $\mathrm{z}$ orzeczoną niepełnosprawnością). Świadczenia na kolejne dzieci nie podlegają kryterium dochodowemu. Ten dochód nie jest uwzględniany przy ustalaniu prawa do innych świadczeń. Według informacji ze strony Ministerstwa Rodziny, Pracy i Polityki Społecznej świadczenie jest wypłacane prawie $4 \mathrm{mln}$ dzieci do 18. r.ż., co stanowi ok. 57 proc. wszystkich dzieci w tym wieku².

Według deklaracji ustawodawcy główną przesłanką wprowadzenia świadczenia było zachęcenie rodzin do posiadania większej liczby dzieci. Zarówno na etapie dyskusji, jak i od pierwszych miesięcy obowiązywania programu w mediach i w dyskusjach ekspertów od polityki społecznej, ekonomii i demografii pojawiały się argumenty za i przeciw nowemu świadczeniu. Krytycy wskazywali na wysoki koszt finansowania świadczeń, negatywnie wpływający na finanse publiczne i wymuszający podniesienie opodatkowania w celu sprostania wyższym kosztom świadczeń w przyszłości. Pisano o braku spójności zasad przyznawania nowych świadczeń z innymi obszarami polityki rodzinnej. Zastanawiano się nad wpływem świadczenia wychowawczego nie tylko na decyzje prokreacyjne Polaków, ale i na ubóstwo rodzin z dziećmi oraz na aktywność zawodową rodziców (zob. np. Arak, 2016; Myck, 2016; Popiołek, 2017; Golinowska i Sowa-Kofta, 2017; Ruzik-Sierdzińska, 2017; Szarfenberg, 2017; Bargu i Morgandi, 2018; Magda et al., 2018). Jednocześnie trzeba zaznaczyć, że program cieszy się dużym poparciem społecznym. Aż 77 proc. respondentów badanych przez CBOS w marcu 2017 r. popierało program Rodzina 500+ (CBOS, 2018).

Niniejszy tekst jest przyczynkiem do dyskusji o krótkookresowych skutkach wprowadzenia w 2016 r. nowego świadczenia. Głównym celem artykułu jest omówienie dotychczasowego wpływu programu Rodzina 500+ na trzy obszary: liczbę urodzeń, ubóstwo w rodzinach z dziećmi i aktywność zawodową rodziców (zwłaszcza matek) małych dzieci. Wykorzystano dostępne dane statystyczne oraz wyniki badań na ten temat.

\section{Skutki programu Rodzina 500+}

Jak wspomniano, obszary, na które opisywany program świadczeń mógł mieć wpływ to: zwiększenie dzietności, zmniejszenie ubóstwa gospodarstw domowych z dziećmi oraz zmniejszenie podaży pracy. W kolejnych podrozdziałach artykułu zostaną omówione kolejno te trzy kwestie. Warto podkreślić, że nie zawsze da się

2 https://www.mpips.gov.pl/aktualnosci-wszystkie/rodzina-500-plus/art,9199,2-62-mln-rodzin-z-500. html, dostęp 5.03.2018. 
jednoznacznie wyodrębnić wpływ tylko świadczenia z programu Rodzina 500+ na omawiane obszary, z powodu zmian innych przepisów i sytuacji gospodarczej zachodzących w tym samym czasie lub wcześniej.

W drugiej dekadzie XXI w. wprowadzono w Polsce istotne zmiany w polityce rodzinnej i rozwiązania ułatwiające godzenie pracy zawodowej oraz życia rodzinnego. Chodzi przede wszystkim o wydłużone w 2013 r. o 26 tygodni urlopy rodzicielskie oraz przyznawane od początku 2016 r. roczne świadczenie rodzicielskie dla matek, które wcześniej nie pracowały (i nie płaciły ubezpieczenia chorobowego).

Zwiększono dostępność opieki przedszkolnej finansowanej ze środków publicznych. Od roku 2017/2018 jest ona zagwarantowana dla wszystkich dzieci od trzeciego roku życia. Obniżono maksymalne finansowane przez rodziców opłaty za każdą godzinę powyżej pięciu godzin dziennie w publicznym przedszkolu, a następnie od 2017 r. zlikwidowano opłaty za pobyt sześciolatków (niektóre gminy zlikwidowały te opłaty także dla młodszych dzieci). Powoli poprawia się też dostęp do opieki nad dziećmi do 3 r.ż.

Polepszająca się od 2012 r. sytuacja na rynku pracy wpłynęła na znaczne obniżenie stopy bezrobocia, wzrost zatrudnienia, a w ostatnich latach na przyspieszenie tempa wzrostu wynagrodzeń nominalnych. Należy jednak podkreślić, że w Polsce od lat utrzymuje się duże zróżnicowanie, jeśli chodzi o sytuację na rynku pracy. Wciąż istnieją powiaty ze stopą bezrobocia przekraczającą 10 proc. lub w których oferowane są głównie prace z niskimi wynagrodzeniami.

\section{Dzietność}

Jedną z przesłanek wprowadzenia nowego kosztownego programu świadczeń było skłonienie Polaków do podejmowania decyzji o posiadaniu większej liczby dzieci, co mogłoby spowolnić zachodzące szybko procesy starzenia się ludności (por. Uzasadnienie..., 2016).

Liczba dzieci urodzonych w każdym roku spadała od rozpoczęcia transformacji systemowej aż do 2003 r., kiedy urodziło się najmniej dzieci w całym okresie powojennym, a następnie rosła do 2009 r., osiągając 418 tys. i znów zaczęła maleć, z niewielkim wahnięciem w górę w 2014 r. Wzrost liczby urodzeń w latach 2004-2009 występował w okresie dobrej sytuacji na rynku pracy i rozwoju gospodarczego, a według demografów był w dużym stopniu efektem realizacji urodzeń „odłożonych”.

Z wyjątkiem krótkich okresów niewielkiego wzrostu współczynnik dzietności od połowy lat $80 . \mathrm{XX}$ w. jest poniżej progu tzw. prostej zastępowalności pokoleń ustalanej na poziomie ok. 2,1 (rysunek 2). 


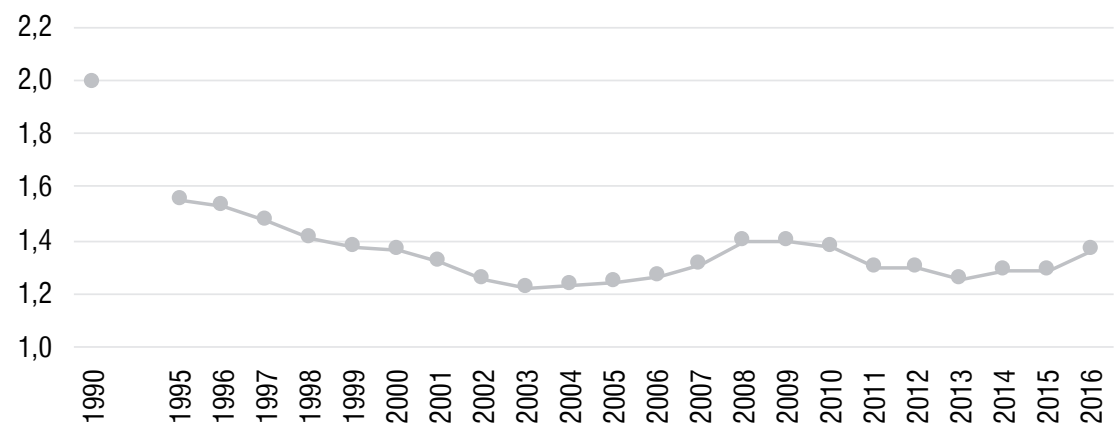

Rysunek 2. Współczynnik dzietności ${ }^{3}$ w Polsce w latach 1990-2016

Źródło: GUS.

W 2016 r. w Polsce urodziło się 383,4 tys. dzieci, o 13 tys. więcej w porównaniu z poprzednim rokiem (GUS, 2017a), zaś wstępne dane mówią, że liczba urodzeń w 2017 r. osiągnęła 403 tys., co bywa interpretowane jako pozytywny wpływ na decyzje prokreacyjne świadczeń z programu Rodzina 500+ oraz innych rozwiązań skierowanych do rodzin z dziećmi. Obecnie jednak nie można ocenić, czy obserwowany wzrost jest skutkiem szybszej realizacji decyzji o posiadaniu dzieci (czyli efektem przejściowym), czy też bardziej pożądanym trwałym wzrostem dzietności.

W krajach europejskich sukces w sferze zwiększania dzietności przyniosła raczej polityka ułatwiająca łączenie pracy z posiadaniem dzieci (Steiber, 2007; Luci-Greulich i Thévenon, 2013). Konieczność wspierania rodziców w obowiązkach opiekuńczych (jeśli chce się jednocześnie mieć wysoką aktywność zawodową i wyższą dzietność) jest skutkiem zmiany ekonomicznego modelu rodziny - obecnie kobiety są lepiej wykształcone i chcą się realizować także na rynku pracy. A zatem zasiłki mają wpływ na dzietność jedynie wtedy, gdy są elementem szerszej polityki ułatwiającej pełnienie obowiązków opiekuńczych.

\section{Ubóstwo}

Jednym z celów świadczeń z publicznego systemu zabezpieczenia społecznego jest ochrona przed ubóstwem osób, które je otrzymują. Samo ubóstwo jest problemem szerszym niż tylko brak wystarczających dochodów (Panek, 2011),

3 Współczynnik dzietności oznacza liczbę dzieci, które urodziłaby przeciętnie kobieta w ciągu całego okresu rozrodczego (15-49 lat) przy założeniu, że w poszczególnych fazach tego okresu rodziłaby z intensywnością obserwowaną w badanym roku, tzn. przy przyjęciu cząstkowych współczynników płodności $\mathrm{z}$ tego okresu za niezmienne. 
jednak w tym opracowaniu zajmiemy się tylko jednym z wymiarów biedy, czyli ubóstwem materialnym.

Przyjmuje się, że gospodarstwo domowe (i jego członkowie) jest ubogie, jeżeli poziom dochodów lub wydatków jest niższy od wartości przyjętej za granicę ubóstwa. W Polsce za granicę ubóstwa skrajnego przyjmuje się tzw. minimum egzystencji, które jest kwotą pozwalającą na minimalną konsumpcję zapewniającą podtrzymanie sprawności psychofizycznej i funkcji życiowych (por. Deniszczuk i Sajkiewicz, 1997). Granicę ubóstwa można także ustalić na poziomie relatywnym. W statystyce GUS przyjmuje się, że gospodarstwa domowe ubogie według granicy relatywnej to te, w których dochody lub wydatki ekwiwalentne wynosiły mniej niż określoną część (40, 50 lub 60 proc.) średnich lub medianowych dochodów albo wydatków wszystkich gospodarstw domowych w kraju. Miara relatywna pokazuje zatem sytuację danego gospodarstwa na tle poziomu zamożności całego kraju. Wielu badaczy uważa, że lepszą miarą zagrożenia biedą są wydatki niż dochody (zob. Atkinson et al., 2002), ponieważ z jednej strony stosowanie tej miary pozwala obejść problem trudności $\mathrm{z}$ informacjami o dochodach nierejestrowanych, a $\mathrm{z}$ drugiej to poziom konsumpcji - mierzony wydatkami - lepiej opisuje standard życia. Podejście dochodowe bywa wykorzystywane np. w badaniach EU-SILC i stanowi podstawę porównań poziomu zagrożenia ubóstwem w różnych krajach europejskich.

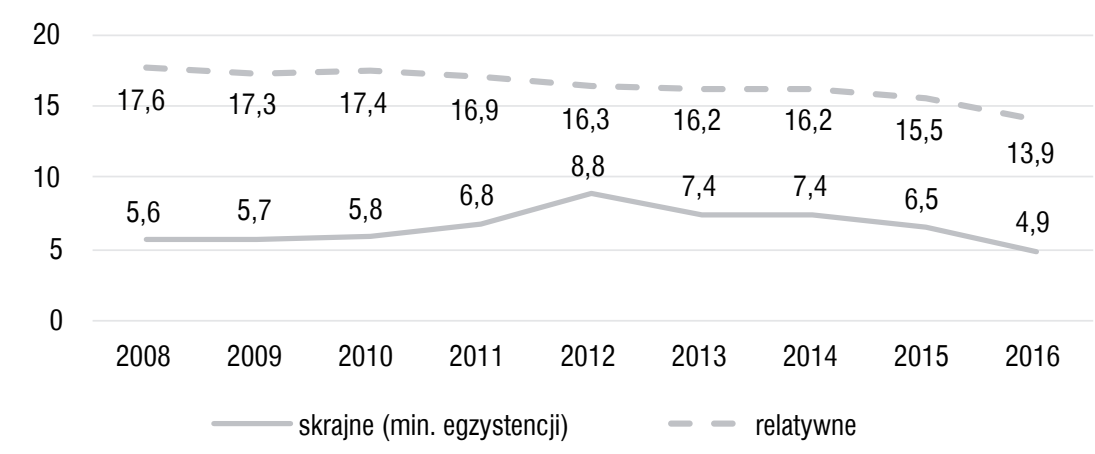

Rysunek 3. Stopa ubóstwa skrajnego i ubóstwa relatywnego w latach 2008-2016 (w proc.)

Uwaga: granica ubóstwa relatywnego to 50 proc. średnich miesięcznych wydatków ekwiwalentnych. Źródło: GUS (2017b).

Ubóstwo relatywne mierzone wydatkami maleje w Polsce od wielu lat, widać również spadkową tendencję ubóstwa skrajnego. Przyczyniły się do tego rozwój gospodarczy, dobra sytuacja na rynku pracy, ale także polityka społeczna, np. korzystne dla rodzin wielodzietnych zmiany w ulgach prorodzinnych. Można oczekiwać, że 
świadczenia $\mathrm{z}$ programu Rodzina 500+ zmniejszyły w rodzinach z dziećmi stopę ubóstwa, czyli mniej ludzi mieszka w gospodarstwach domowych $\mathrm{z}$ dochodem poniżej ustalonego poziomu.

Tabela 1 pokazuje, że konstrukcja programu w największym stopniu zmniejszyła ubóstwo rodzin z większą liczbą dzieci, znacząco spadło ubóstwo skrajne. W 2016 r. w porównaniu $\mathrm{z}$ rokiem poprzednim relatywnie najbardziej spadło ubóstwo skrajne rodzin z dwójką dzieci - o jedną trzecią ( 4 proc. do 2,7 proc.) oraz rodzin z trójką dzieci - prawie o połowę (zmiana z 9 proc. na 4,7 proc.). Mimo znacznego spadku ubóstwa wśród rodzin z czwórką i większą liczbą dzieci, wciąż 14 proc. z nich jest poniżej poziomu skrajnego ubóstwa.

Można oczekiwać, że zmniejszyła się również głębokość ubóstwa, czyli różnica między dochodami osób ubogich a progiem ubóstwa - dokładne oszacowanie zmian wymagałoby jednak pogłębionych analiz danych indywidualnych.

Tabela 1. Zasięg ubóstwa wg typów gospodarstw domowych (w proc.)

\begin{tabular}{|l|c|c|c|c|c|c|}
\hline \multirow{2}{*}{\begin{tabular}{c}
\multirow{2}{*}{$\begin{array}{c}\text { Struktura } \\
\text { rodziny }\end{array}$} \\
\cline { 2 - 7 }
\end{tabular}} & $\mathbf{5}$ & \multicolumn{3}{c|}{ Relatywna granica ubóstwa } \\
\hline Ogółem & $\mathbf{7 , 4}$ & $\mathbf{6 , 5}$ & $\mathbf{4 , 9}$ & $\mathbf{1 6 , 2}$ & $\mathbf{1 5 , 5}$ & $\mathbf{1 3 , 9}$ \\
\hline Rodzic z dziećmi & 5,6 & 6,5 & 5,6 & 14,5 & 13,5 & 12 \\
\hline Małżeństwa/związki: & 1,8 & 1,6 & 1,8 & 5,2 & 5,3 & 5,9 \\
\hline bez dzieci & 2,7 & 1,8 & 1,7 & 6,4 & 6,6 & 6,5 \\
\hline z 1 dzieckiem & 4,5 & 4 & 2,7 & 11,2 & 11,8 & 10 \\
\hline z 2 dzieci & 11,2 & 9 & 4,7 & 24,1 & 21,8 & 16,5 \\
\hline z 3 dzieci & 26,9 & 18,1 & 14 & 48,3 & 45 & 33,6 \\
\hline z 4 + dzieci & & & & & \\
\hline
\end{tabular}

Źródło: GUS (2017c).

Wstępna analiza danych badania budżetów gospodarstw domowych za 2016 rok Golinowskiej i Sowy-Kofty (2017) pokazuje, że świadczenie zmniejszyło ubóstwo, ale i poprawiło strukturę konsumpcji wszystkich członków gospodarstw domowych $\mathrm{z}$ dziećmi.

Jak wskazuje Szarfenberg (2017) trudno uznać, że to tylko świadczenie w wysokości 500 PLN przyczyniło się do obserwowanego spadku ubóstwa. Zmiana była kontynuacją wieloletniego trendu zwiększania dochodów ludności i zachodziła przy polepszającej się sytuacji na rynku pracy. A zatem wpływ na obniżenie ubóstwa mogły mieć również większe szanse na znalezienie pracy (bardzo niskie bezrobocie) i rosnące wynagrodzenia. 


\section{Rynek pracy}

Współczynnik aktywności zawodowej to udział osób aktywnych zawodowo (pracujących i bezrobotnych) w ogólnej liczbie ludności danej kategorii. Analiza tej miary dla kobiet w wieku 25-39 lat pokazuje, że od 2015 r., a dla niektórych grup wieku nawet wcześniej, widoczny jest trend spadkowy aktywności zawodowej (z wahaniami sezonowymi, charakterystycznymi dla polskiego rynku pracy), szczególnie widoczny w ostatnim roku i dla młodszych kobiet (rysunek 4).

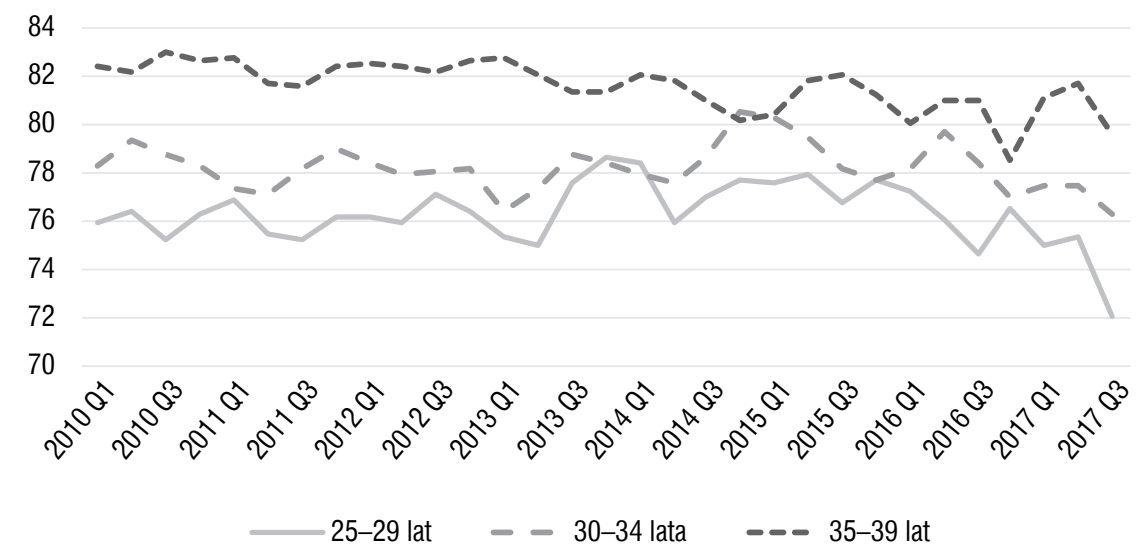

\section{Rysunek 4. Współczynnik aktywności zawodowej kobiet w wieku 25-39 lat od 2010 do $2017 \mathrm{r}$.}

Źródło: GUS BAEL.

W ekonomii pracy przyjmuje się, że na chęć do podejmowania zatrudnienia wpływają m.in. dochody spoza pracy. W szczególności świadczenia społeczne, których otrzymanie jest uzależnione od dochodów mogą powodować, że podejmowanie pracy nie daje dużych korzyści, jeśli jednocześnie oznacza utratę prawa do świadczenia przysługującego z uwzględnieniem kryterium dochodowego. Wstępne informacje na ten temat może nam dać analiza sytuacji osób, które mają małe dzieci. Okazuje się, że w danych widać wyraźne różnice aktywności zawodowej w zależności od liczby dzieci, w szczególności w wieku do sześciu lat. Wśród mężczyzn i bezdzietnych kobiet aktywność zawodowa w ostatnich latach wzrosła, zaś spadała wśród kobiet $\mathrm{z}$ dziećmi.

Niższa aktywność zawodowa kobiet $\mathrm{z}$ większą liczbą dzieci nie jest już widoczna w gospodarstwach domowych, w których najmłodsze dziecko ma 6-11 lat, czyli chodzi już do szkoły i jest bardziej samodzielne. 


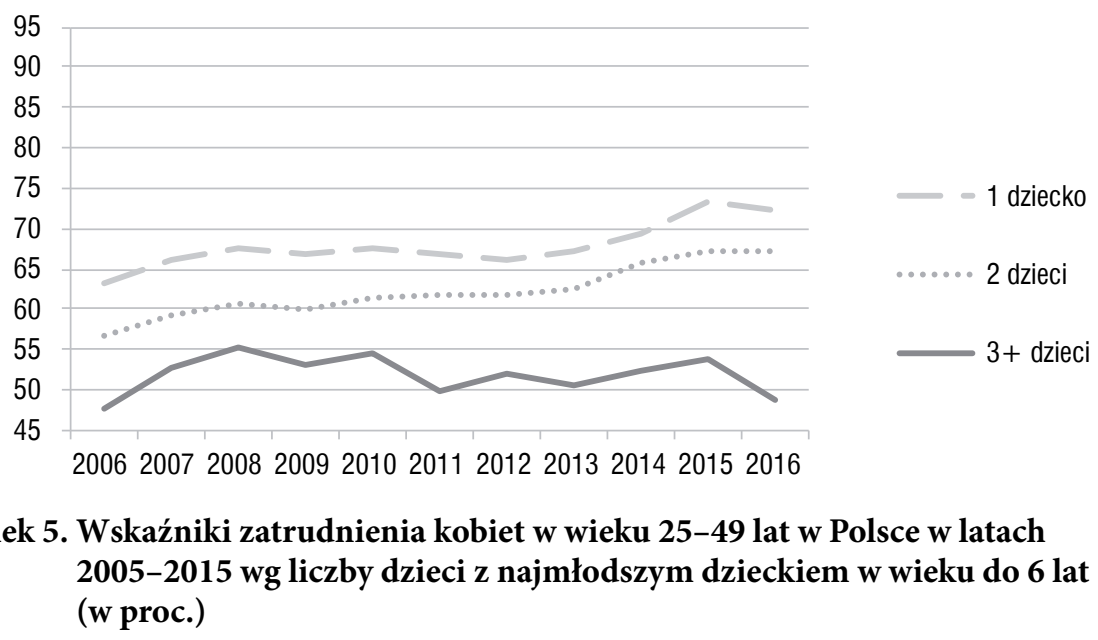

Źródło: Eurostat.

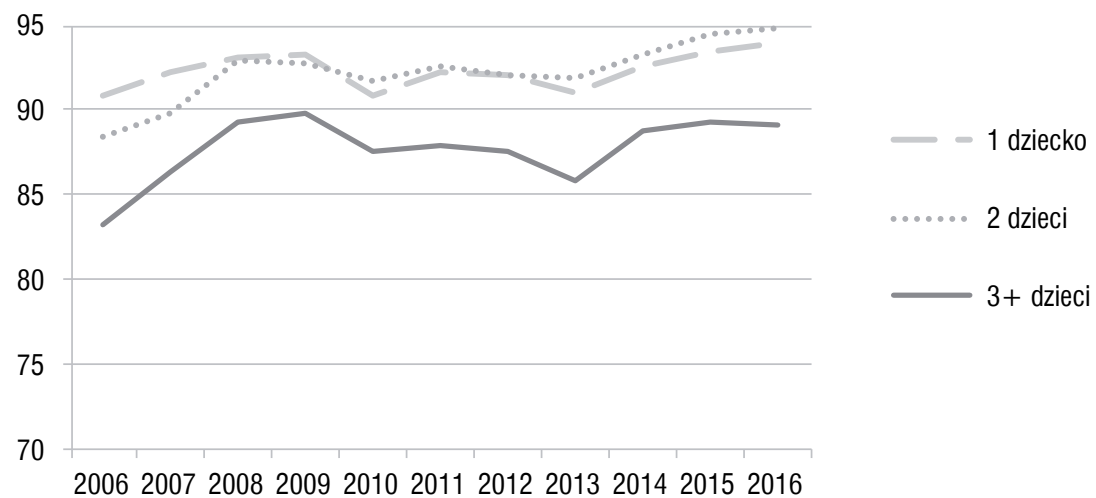

Rysunek 6. Wskaźniki zatrudnienia mężczyzn w wieku 25-49 lat w Polsce w latach 2005-2015 według liczby dzieci $z$ najmłodszym dzieckiem w wieku do 6 lat (w proc.)

Źródło: Eurostat.

Które kobiety wycofują się z rynku pracy najczęściej i ilu dokładnie osób to może dotyczyć? Według badania CBOS (2018) przeprowadzonego w marcu 2017 r. 12 proc. respondentów zetknęło się osobiście z wypadkiem rezygnacji z pracy zawodowej matki w rodzinie otrzymującej świadczenie wychowawcze.

Jednym z pierwszych naukowych opracowań po wprowadzeniu programu była analiza Mycka (2016), który na podstawie teoretycznego modelu oszacował, że ograniczenie aktywności zawodowej rodziców może dotyczyć około 235 tys. osób, przy czym ten szacunek obejmował okres wielu lat po wprowadzeniu nowego świadczenia. Autor ocenił, że z pracy będą rezygnowały głównie kobiety (co potwierdzają 
dostępne dane do III kwartału 2017 r.), osoby z niższym lub średnim wykształceniem, zarabiające relatywnie mało i mieszkające w mniejszych miastach lub na wsi.

W publikacji Magdy et al. (2018) oszacowano, że ok. 2,4 pkt proc. obserwowanego do połowy 2017 r. spadku w aktywności zawodowej matek było spowodowane świadczeniem z programu Rodzina 500+.

Wskazanie tych grup jako najbardziej podatnych na dezaktywizację zawodową zgodne jest z raportem autorstwa Bargu i Morgandiego (2018). Pokazali oni, że omawiany program silnie zniechęca do podjęcia pracy, w szczególności osoby dorosłe w rodzinach z najniższego kwintyla rozkładu dochodów. Wpływ ten jest szczególnie silny na samotne matki i drugie osoby dorosłe w rodzinie, w której jedno z rodziców już pracuje za niskie wynagrodzenie. Po uwzględnieniu kosztu prywatnej opieki nad małymi dziećmi rośnie liczba rodzin, które finansowo straciłyby po podjęciu pracy przez drugą osobę dorosłą albo samotnego rodzica. Zwiększenie dostępu do niedrogiej i dobrej jakości opieki nad małymi dziećmi zmniejszyłoby negatywny wpływ omawianego świadczenia na podaż pracy.

Empiryczne oszacowania Ruzik-Sierdzińskiej (2017) na podstawie danych dla 2016 roku mówią o liczbie między 20 a 33 tys. kobiet, które mogły odejść z rynku pracy w pierwszych kwartałach od rozpoczęcia programu. Liczby te nie uwzględniają osób, które zrezygnowały z powrotu do pracy po urlopie macierzyńskim ani osób bezrobotnych, które stały się bierne zawodowo, bo przestały szukać zatrudnienia. Z kolei opracowanie Magdy (2017) pokazuje, że program Rodzina 500+ zwiększył odpływy kobiet nie tylko z zatrudnienia, ale też z bezrobocia do bierności zawodowej. Oznacza to, że część bezrobotnych matek przestało szukać pracy. Szacowana w raporcie wielkość odpływu do bierności w drugim półroczu 2016 r. to liczba między 40 a 55 tys. osób. Warto podkreślić, że na podstawie dostępnych danych na razie nie można sprawdzić, czy obserwowany spadek podaży pracy kobiet $\mathrm{z}$ dziećmi to efekt jednorazowy i czy chodzi o wycofanie się z rynku pracy na dłużej czy krócej. W miarę pojawiania się kolejnych informacji statystycznych należałoby także zbadać wpływ wprowadzonego programu na zatrudnienie w szarej strefie bądź wypłacanie części wynagrodzeń w nierejestrowanej formie.

Obniżenie podaży pracy należy uznać za negatywny efekt programu świadczeń 500+. Badania dla innych krajów pokazują, że nawet okresowe odejście z rynku pracy może mieć negatywny wpływ na perspektywy zawodowe i przyszłe zarobki matek (Lalive i Zweimüller, 2009). W lepszej sytuacji są kobiety w krajach, gdzie łatwiej można znaleźć pracę na część etatu, kiedy w rodzinie są małe dzieci, niż gdy trzeba zupełnie odejść z rynku pracy (Drange i Rege, 2013). Dłuższe przerwy w aktywności na rynku pracy to większe trudności w znalezieniu atrakcyjnego zatrudnienia po powrocie na rynek pracy. Oznacza to też większe zagrożenie ubóstwem 
na emeryturze - wysokość emerytury zależy bowiem od liczby lat pracy i płacenia składek emerytalnych. Wreszcie rezygnacja z pracy rodziców osłabia wpływ programu Rodzina 500+ na zmniejszenie ubóstwa rodzin z dziećmi.

\section{$* * *$}

W artykule omówiono możliwy wpływ programu Rodzina 500+ na liczbę urodzeń, ubóstwo w rodzinach z dziećmi i aktywność zawodową rodziców. Przeprowadzono analizę danych statystycznych dostępnych na początku 2018 r. oraz omówiono badania na ten temat powstałe od $2016 \mathrm{r}$.

W okresie obowiązywania nowych regulacji dotyczących świadczeń dla rodzin z dziećmi wzrosła liczba rodzących się dzieci i nieznacznie wzrósł współczynnik dzietności. Obecnie jednak trudno jest ocenić, czy obserwowany wzrost jest realizacją odłożonych w czasie urodzeń, głównie przez kobiety należące do pokolenia wyżu demograficznego urodzonego w latach 80 . XX w., czy też oznacza bardziej trwałe podniesienie się dzietności. Obserwowany efekt może być związany także z innymi zmianami polityki rodzinnej wprowadzanymi w latach 2013-2016 (zwiększenie dostępności opieki nad małymi dziećmi i świadczenie rodzicielskie dla osób nieposiadających ubezpieczenia chorobowego). Warto tu przytoczyć deklaracje Polek w wieku 18-33 lata przebadanych kilka lat temu przez CBOS na temat planów prokreacyjnych. Spośród kobiet, które deklarowały, że nie planują dzieci, połowa jako przyczynę wskazywała złą sytuację materialną, a co trzecia spodziewany konflikt między obowiązkami zawodowymi i rodzinnymi (CBOS, 2013).

Istotnie zmniejszyło się ubóstwo rodzin z dziećmi, bardziej niż wynikałoby to $\mathrm{z}$ tendencji spadku ubóstwa w Polsce, widocznej przynajmniej od 2012 r. Redukcja ryzyka ubóstwa była najsilniejsza wśród rodzin z trojgiem i większą liczbą dzieci oraz znacząco obniżyła ubóstwo skrajne, czyli odsetek rodzin z dochodem poniżej minimum egzystencji. Warto przypomnieć, że ponieważ świadczenie w wysokości 500 PLN nie jest brane pod uwagę przy ustalaniu dochodu uprawniającego do innych świadczeń, może ono powodować, że rodziny z dziećmi są w korzystniejszej sytuacji od ubogich rodzin bez dzieci.

Jednocześnie w ostatnich latach zaobserwowano (niezamierzony?) niekorzystny wpływ programu Rodzina 500+ na rynek pracy. W Polsce od lat mówi się o konieczności zwiększenia aktywności zawodowej w każdej grupie wieku, zaś nowy system świadczeń rodzinnych sprawił, że dla części rodziców podejmowanie pracy stało się finansowo nieopłacalne, szczególnie gdy uwzględnimy koszty zapewnienia opieki małym dzieciom w czasie pracy obojga rodziców oraz małą popularność w Polsce pracy w niepełnym wymiarze czy elastycznego sposobu organizowania czasu pracy. Rezygnacja z pracy czy poszukiwania pracy może dotyczyć według różnych szacunków 
od 20 do ponad 50 tys. osób, głównie kobiet mieszkających w mniejszych miejscowościach i z wykształceniem niegwarantującym wysokich zarobków. Konstrukcja programu stwarza też potencjalnie zachęty do zatrudnienia w szarej strefie, z której dochody nie wpływają na prawo do pobierania świadczenia na pierwsze dziecko $\mathrm{w}$ rodzinie.

Podsumowując, ponieważ koszt programu Rodzina $500+$ to nawet 1,3 proc. PKB rocznie, należy monitorować wpływ tego rozwiązania na różne obszary tak, aby ograniczyć niekorzystne efekty uboczne świadczenia.

\section{Bibliografia}

Arak, P. (2016). Pro-family Policy in Poland and around the World, Central European Financial Observer. https://financialobserver.eu/poland/pro-family-policy-in-poland-and-aroundthe-world/, dostęp 10.04.2018.

Atkinson, T., Cantillon, B., Marlier, E. i Nolan, B. (2002). Social Indicators - the EU and Social Inclusion. Oxford: Oxford University Press.

Bargu, A. i Morgandi, M. (2018). Can Mothers Afford to Work in Poland? Labor Supply Incentives of Social Benefits and Childcare Costs. Policy Research Working Paper, No. 8295. World Bank: Washington, DC.

CBOS (2013). Postawy prokreacyjne Polek, Raport nr BS/29/2013. Fundacja Centrum Badania Opinii Społecznej: Warszawa.

CBOS (2018). Postrzeganie programu Rodzina 500 plus, prezentacja z konferencji. https://www.cbos. pl/PL/wydarzenia/66_konferencja/Rodzina_500plus_CBOS_2018.pdf, dostęp 10.04.2018.

Deniszczuk, L. i Sajkiewicz, B. (1997). Kategoria minimum egzystencji, w: S. Golinowska, Polska bieda II. Kryteria - Ocena - Przeciwdziałanie. IPiSS: Warszawa.

Drange, N. i Rege, M. (2013). Trapped at Home: The Effect of Mothers' Temporary Labour Market Exits on their Subsequent Work Career. Labour Economics, 24 October: 125-136.

Golinowska, S. i Sowa-Kofta, A. (2017). Combating Poverty through Family Gash Benefits: on the First Results of the Programme "Family 500+" in Poland. Polityka Społeczna, nr 1:7-13.

GUS (2017a). Rocznik Demograficzny 2017. GUS: Warszawa.

GUS (2017b). Budżety gospodarstw domowych $w 2016$ r. GUS: Warszawa.

GUS (2017c). Ubóstwo w Polsce w latach 2015 i 2016. GUS:Warszawa.

Lalive, R. i Zweimüller, J. (2009). How Does Parental Leave Affect Fertility and Return to Work? Evidence from Two Natural Experiments. The Quarterly Journal of Economics, Vol. 24, No. 3: 1363-1402.

Luci-Greulich, A. i Thévenon, O. (2013). The Impact of Family Policies on Fertility Trends in Developed Countries. European Journal of Population, Vol. 29, No. 4: 387-416.

Magda, I., Kielczewska, A. i Brandt N. (2018). The "Family 500+" Child Allowance and Female Labour Supply in Poland. IBS Working Papers, No. 1. Instytut Badań Strukturalnych: Warszawa. 
Myck, M. (2016). Estimating Labour Supply Response to the Introduction of the Family 500+ Programme, CenEA Working Paper, No. 1.

Panek, T. (2011). Ubóstwo, wykluczenie społeczne i nierówności, Oficyna Wydawnicza SGH: Warszawa.

Popiołek, A. (2017). 23 mld zł kosztuje budżet program "Rodzina 500 plus". Opłaca się?. Gazeta Wyborcza, 2.04.

Ruzik-Sierdzińska, A. (2017). Czy program "Rodzina 500+" wywołał efekt na rynku pracy?. Analiza 2017/15. Instytut Obywatelski: Warszawa.

Steiber, N. (2007). The Linkages between Work and Family: State of Knowledge and Policy Implications. Equal.Soc. Policy Paper, Vol. 2.

Szarfenberg, R. (2017). Wpływ świadczenia wychowawczego (500+) na ubóstwo ogółem i ubóstwo dzieci na podstawie mikrosymulacji. http://rszarf.ips.uw.edu.pl/pdf/wplyw500+.pdf

Uzasadnienie do rządowego projektu ustawy o pomocy państwa w wychowywaniu dzieci (2016), druk sejmowy nr 216. 
